\title{
AN ANALYSIS OF POLITENESS STRATEGIES USED BY TEACHER AND STUDENTS OF X IBB IN SMAN 1 SUKASADA DURING ENGLISH CLASSROOM INTERACTION
}

\author{
Widana, I.M. ${ }^{1}$, Swandana, I.W. ${ }^{2}$, Wedhanti, N.K. \\ ${ }^{1}$ Ganesha University Of Education, Singaraja, Indonesia \\ ${ }^{2}$ Ganesha University Of Education, Singaraja, Indonesia \\ ${ }^{3}$ Ganesha University Of Education, Singaraja, Indonesia
}

\author{
A R T I C LE IN F O \\ Article history: \\ Received 19 March 2018 \\ Received in revised form \\ 10 April 2018 \\ Accepted 12 May 2018 \\ Available online 26 June \\ 2018 \\ Keywords: \\ Face Threatening Acts, \\ Politeness Strategy, \\ Factor Influencing \\ Politeness Strategy Choice.
}

\begin{abstract}
A B S T R A C T
This study aims to (1) analyzing the types of politeness strategies used by teachers and students of Class X in Ilmu Budaya dan Bahasa (IBB) in Sekolah Menengah Atas Negeri 1 Sukasada during English classroom interaction; (2) analyzing the factors that influence the choice of politeness strategies. This study was designed as a qualitative descriptive study. The data that has been obtained was analyzed based on the theory of politeness Brown and Levinson's strategy. The results of this study indicated that (1) there were three types of Brown and Levinson politeness strategies used by teachers and students namely bald on record, positive politeness, and negative politeness; (2) as for the factors that influencing the choice of politeness strategies are payoffs: as a prior consideration, circumstances: social variables, and integration of the assessment of payoffs and the weight of the risk of choosing politeness strategies.
\end{abstract}

\section{Introduction}

Communication is the way that is used by people to make a relationship to each other. Other than that, people also communicate to others to share the information in their daily life. It is supported by Management Training and Development known as [8] defined the communication is the art and process of constructing and sharing the information. Thus, a communication is an important thing to be conducted in daily life to have a good relationship and sharing information. However, It does not mean the communication always makes people have good relationship to the others. It depends on the people in using the language when communicated to the others. As stated by [9] that the interlocutor has to work hard to choose proper language to make the effective communication in social relationship. Therefore, the effective communication that is done by the interlocutor depends on the way of using language.

Considering the important of language that is used to convey the information in the communication, there are two types of language that can be used in communication namely verbal and nonverbal language. Verbal language is the use of words by human to send the message in communication and nonverbal language is the use of body language. In addition, the verbal language is the words that we choose to communicate to each other, it can be orally or written [8]. However, nonverbal language is the subconscious message that is communicated by using body language. Therefore, the verbal and nonverbal languages are the tools that can be used by people to send the information in communication.

It is same in daily teaching and learning process, the teacher and the students also need to use language in sharing and confirming the knowledge. The teacher and the student do a communication in classroom or they conducted the classroom interaction. In other hand, the language plays an important 
role in teaching and learning process [10]. Therefore, the successes of sharing knowledge in teaching and learning process are determined by the success of classroom interaction.

As stated before, other than using language to share information, the teacher and the students need to use language in making a good relationship between them. The relationship between teacher and students are required in classroom interaction. It is because the knowledge that is delivered by the teacher and received by students will run well if the classroom interaction runs well [6]. However, the relationship is only as limited as a teacher and students. The relationship is notcloser than that or vice versa.

Further, there is a case when the interlocutor does not use proper language in communication and result the audience become disrespect to the interlocutor. As example in classroom interaction, a student becomes not respect to the teacher who does not call the student's name but using pronoun you when criticize the students misbehavior. As stated by [11] that the pragmatic knowledge, which is owned by the students and teacher will influence the behavior and the response in different situation and context. It is also supported by [6]who stated that students would imitate the way the teacher teaches them because the teacher takes role as model in classroom. Thus, it can be said that if the manner treatment is good, the response will also good.

Therefore, a well strategy to indicate a good etiquette in a communication is needed to get a good response from the audience. Then, one of the appropriate communication strategies toward that case is politeness strategy. It is because politeness is regarded as a moral code in human communication and social activities [9]. In addition, they said that the application of politeness strategy that is conducted by teacher and students in using language in EFL classroom would affect the learning atmosphere become positive. In simply way, the interlocutor should fulfill the audience's desire first if the interlocutor wants the audience fulfill his/her desire.

According to[3]there are four main type of politeness strategies. Those are bald on-record (direct), positive politeness, negative politeness, and off record (indirect). Those politeness strategies are used to satisfy the specific wants of face and realizing the various strategies that are used by various people in their transactional behavior.The four types of politeness are described as follow bellow:

Bald on record is suitable with Grice's Maxim theory which the use of this strategy in simply way. Then, Positive politeness is defined as the strategy that speaker orients hearer's positive face that speaker claims to himself. Next, negative politeness strategy is the redressive action, which is addressed to the addressee's negative face or (his want to have his freedom of action unhindered and his attention unimpeded). Last, off record is a type of politeness that is done by the speaker if the speaker wants to do an FTA but the speaker wants to avoid the responsibility in doing it

Based on Brown and Levinson's theory of politeness strategy, the researcher takes four journals as previous study to support the study in scope of politeness strategy. First, an article entitled Speech Acts and Politeness Strategies in an EFL Classroom in Georgia that is conducted by [5]. The researcher studied about the students' and the teacher' practice of the politeness strategies and the speech acts of apology, thanking, request, compliment/encouragement, command, agreeing/disagreeing, addressing and code switching.

In the study, the researcher applied observation method that includes questionnaire and involved two target group namely students and experienced local English teachers from Georgian public schools. Then, the study resulted that the students have certain knowledge regarding politeness and they still fail to use them in English communication. In addition, the teachers use the most of the speech acts from the classroom interaction and not the students.

Second, an article entitled A Case Study of College Teacher's Politeness Strategy in EFL Classroom that is conducted by[9]. The research has aim to reveal how the teacher applies politeness strategies to his teaching practice in the language use. By adopting Brown and Levinson theory of politeness strategy, they conducted class observation method to collect the data. The participants in this study are a younger teacher who is 30 years old and 30 students that consist of 28 boys and 2 girls. Then, the result is the college teacher conducts his class in term of positive politeness and negative politeness in a practical way.

Third, an article entitled Politeness Strategies in Teacher-Student Interaction in an EFL Classroom Context that is conducted by [11]. The study explored politeness strategies used by teacher and students in two 90-minutes English lessons in a senior high school. The participants in the study are two non-native English teachers (42-year-old male and 36 years-old female) and 59 students in two different classes. The students in the English lesson were the 11th graders in SMA Negeri 2 Semarang.

The researchers used video recorder as a medium to collect the data in the study and it showed that teacher and students employed positive, negative, and bald on record strategies. Teacher and students' perception on social distance, the age difference, institutional setting, power, and the limitation of the linguistic ability of the students has contributed to the different choices of politeness strategy. 
Then the fourth, an article entitled Politeness and Power Relation in EFL Classroom Interactions: A Study on Indonesian Learners and Lecturers that is conducted by [1]. The purpose of study is to raise the awareness of the English lecturers to use language manner during the classroom interaction and to create effective communication through the dimension of politeness. In this study, the research applied descriptive qualitative method and use a video recorder as the medium to record the classroom interaction. Then, the participants in this research are 97 (ninety-seven) Students and the selected six English Department lecturers in UniversitasNegeri Malang. It resulted that some expressions that are generated by lecturers in the classroom possibly implying threatening acts which may impose the students' esteem.

The researcher chooses Ilmu Budaya dan Bahasa (IBB) X grades in SMA N 1 Sukasada as the subject of research. SMA N 1 Sukasada is one of Senior High School in Singaraja that is located in Jl. Jelantik Gingsir No 81 B. The students and the teachers in this school come from Buleleng regency. Furthermore, their daily life school dominantly uses language, which is Buleleng people usually use to communicate to each other. Buleleng people have unique language that is used in communication. They use language that is known by other regency in Bali as impolite language. The language that they use such as cai kije gen ling ibi? "where do you go from yesterday?", this utterance can be responded negatively by people in Karangasem and Gianyar regencies but it is usual to be used by people in Buleleng regency.

Based on that case, the researcher was interested in find out the utterances between teachers and students in English class based on Brown and Levinson politeness theory. Some reasons of the researcher choose Brown and Levinson Theory of politeness strategy and the objects were; by knowing, comprehending, and applying a politeness strategy we as social creature can have a good relationship to the other people. It was supported by Yule (1996) as cited in [6] who stated the politeness strategy is important to investigate to knowing what to say, how to say, when to say, and how to be with other people in conducting social interaction. Moreover, the classroom is the place where the interaction process between teacher and students occurred that must be polite and effective. Then, the second reason, the teacher might apply the politeness strategy of Brown and Levinson and students to satisfy each other face in communication.

Moreover, the reasons choose IBBX grades in SMA N 1 Sukasada because those classes are the lowest grade in a senior high school. The ten grades in this year applied new curriculum namely Curriculum 2013 in their learning and teaching process. The curriculum 2013 or known as K-13 emphasizes on authentic assessment, (affective, cognitive and psychomotor) of competency aspects, get more learning time allotment in a week, using scientific approach, and using Technology Communication and Information as learning media not as subject matter. Furthermore, there was a case where some classes dominantly showing less respect to an English teacher when the teacher was conducting learning and teaching process but IBB X grades shown different respect from the other X grade classes toward the English teacher in the pre observation that was conducted. Based on those reasons, IBB X grades in SMA N 1 Sukasadawas chosen as the subject of this research.

The research conducted the observation in several meetings. It was because researcher wants to know the consistence of teachers and students' utterance in using politeness strategies during learning process. Based on the description above, the specific objectives of this study are to find out types of politeness strategies Brown and Levinson theory used by teachers and students of X IBB in SMA N 1 Sukasada during English classroom interaction and to find out the factors caused teachers and students of $\mathrm{X}$ IBB in SMA N 1 Sukasada to use politeness strategies during English classroom interaction.

\section{Methods}

This research involved descriptive qualitative data. It was because the data collected through words and picture forms rather than number [2]. In addition, the method of collecting the data will be collected by applying triangulation method. Then, the instruments that are involved in this research is researcher, audio recorder (mobile recorder), and field note. In addition, the research type in this study is observational case studies. It is because the study focuses on Brown and Levinson' politeness strategy used by teacher and students of IBB X grades in SMA N 1 Sukasada during classroom interaction. This research is conducted in SMA N 1 Sukasada especially in X IBB classroom interaction. The subject of this research was the students and teacher in X IBB 1 and X IBB 2 grades. Furthermore, Passive participative observation, semi structure interview and field note were employed as a triangulation technique of collecting the data in this research. The data coding was applied in this research to easy in classifying the data. 
In collecting the data, the researcher sat at the back of classroom from the beginning until the end of lesson while recording utterance in classroom interaction and note.The data that had been collected such as classroom interaction transcript, field note, and interview transcript were analyzed by applying Miles and Huberman in [12] model. Data Reduction was applied by the researcher to lessen the data that is not applicable based on Brown and Levinson theory. Furthermore, the data that had been done analyzed by the expert judges. Next, the data was displayed in formed of the table. After that, conclusion drawing/verification, valid data was concluded in the end of this process.

\section{Findings and Discussion}

This research resulted that the type of politeness strategies that were used by the teacher and students of X IBB in SMAN 1 Sukasada were bald on record, positive politeness, and negative politeness. In other words, only three types of politeness strategies of Brown and Levinson were found in this research. The calculation of each type of politeness strategies is presented in the form of table 3.1.

Table 1. The Occurrences of Each Type of Politeness Strategies

\begin{tabular}{lll}
\hline Types of politeness & $\begin{array}{l}\text { Occurrences } \\
\text { Number of utterances }\end{array}$ & In percentage (\%) \\
\hline Bald on record & 44 & $20 \%$ \\
Positive politeness & 78 & $36 \%$ \\
Negative politeness & 94 & $44 \%$ \\
Total & 216 & $100 \%$ \\
\hline
\end{tabular}

Table 3.1 shows the occurrences of utterances that were produced by teacher and students of $\mathrm{X}$ IBB in SMAN 1 Sukasada. 216 utterances were categorized as politeness strategies. The table shows that bald on record, positive politeness, and negative politeness appeared 44, 78, and 94

The most dominant type of politeness strategies used by teacher and students of X IBB in SMAN 1 Sukasada was negative politeness. It was followed by positive politeness, and bald on record. The teacher and the students dominantly used the negative politeness type. It was because it can be used to maintain the action that was wanted by the interlocutor to not impinge the listener negative face and give a choice to do something. In addition, the positive politeness type was used because the teacher tried hard to use proper and polite language in learning and teaching process. The teacher claimed the students' positive face as the orientation in communication in order to maintain the relationship and vice versa. Then, bald on record was used because the efficiency of the utterance was thought more urgent than other thing.

Further, the factors influencing the choice of politeness strategieswere employed in this research. The payoffs: a prior consideration was influencing the choice of politeness strategy when the teacher and the students applied positive politeness to fulfill the listener's desire first before the listener fulfilled the speaker's desire in the communication. In addition, the circumstances: sociological variables was affected the choice of politeness strategy when the teacher and the students applied negative politeness to remind their own role in communication. Then, the integration of assessment of payoffs and weighting of risk in the choice of strategies were influencing the choice of politeness strategy when the teacher and the students applied bald on record to minimize the face threatening acts.

The teacher and the students used politeness some politeness strategy in their communication during classroom interaction. The politeness strategies were used in the beginning, main activity and ending of lesson activity. However, among four type of Brown \&Levinsons' politeness strategies, off record was most rare used or it did not apply by the teacher and the students in their interaction. It similar with previous study that was conducted by [4] that resulted negative politeness was applied more than positive politeness.

The teacher and the students applied positive politeness strategy by claiming hearer's positive face. The example of positive politeness strategies that were used by the teacher and the students during classroom interaction were describe as follow:

When the teacher said "Do you hear it Ari? Ari Kusuma Jaya hear what I said before", the teacher applied use in-group identity markers positive politeness strategy to fulfill the students wants to be paid attention by the teacher. The code switching in group dialect was involved in the teacher utterance where first name "Ari" and become "Ari Kusuma Jaya". Furthermore, when the teacher said "Permission to go out", the teacher applied seek agreement of positive politeness strategy. The teacher repeat entire information that was given by the students to fulfill students' wants to be respected by the teacher. 
Then, when the teacher said "The plan is if you are ready today to get the last chapter test. Please later on we will conduct it together but if you are not ready, it can be postponed to next meeting on Tuesday next week. It's up to you, if you are ready today for an hour of lesson hours it's good but if you are not ready it can be postponed to next meeting on Tuesday next week", the teacher applied give reason positive politeness strategy. The teacher give a reason that the last chapter test will be better to conducted in next meeting. Other than that, the utterance also indicates the corporation between teacher and students to prepare their selves in conducting the test.

Further, when the student said "Sttt...", the students applied presupposes common ground positive politeness strategy. The student used the language code to make the other students calm and pay attention to the teacher. Furthermore, when the student said "Let us pray together." The student applied including both speaker and hearer in the activity positive politeness strategy. The utterance was polite expression in including someone to do something.

Based on the result of observation, it indicated that the teacher and the students were interacting by using politeness strategy in the classroom interaction. It showed that the students already accustomed to used politeness strategy while interacting with teacher and their friends. This result was similar with the previous study that conducted by [7] who studied about Developing Students' Intelligent Character through Linguistic Politeness: The Case of English as a Foreign Language for Indonesian Students.

The teacher and the students used negative face in their utterance to redress the action in communication. They used it to minimize the FTA in their communication in specific wants and focus on it. The students dominantly used give difference of negative politeness in responding teacher's utterances and the teacher dominantly used beconventionally indirect of negative politeness in asking the students to do something. Those strategies were used in their interaction in the classroom.

The students employed give difference of negative politeness to show their respect to the teacher, the student said "on Wednesday next week sir" to ask the information. Other than that, the students often used it when the teacher called their name to check students' attendance. The students said "Me sir" when their name was called by the teacher. Those students' statements used honorific word namely "sir" to humbles and lower the utterances. In addition, the students used the honorific word to fulfill teacher's superior.

In other side, the teacher often redressed the action by employing be conventionally indirect of negative politeness strategy to solve the opposite tension of the interaction. The teacher said "The student who has not done his/her assignment please collect it today. I wait until two pm this day". It utterance was used when the teacher has a specific want that the students should do. The teacher used utterance "please collect it today" that indicated the teacher gave the students a choice by being indirect to do not impinge students' negative face.

The other utterances that indicated the teacher employed be conventionally indirect of negative politeness strategy during classroom interaction were the teacher said "Please identify with your pairs the theme of song lyric". Then, the next utterance the teacher said "Then, the second one please choose there is $a, b, c, d$, or e". The use of word "please," indicated that the teacher gave the students choice and conveyed the utterance efficiently were applied to redress the students' action through utterances.

The teacher and students used bald on record when they conveyed the utterance in simply way and have clarity meaning. They used some simple utterance during classroom interaction to save the time. The utterance that indicated teacher applied bald on record politeness strategies were when the teacher said "Let me have your attention please." The teacher applied metaphorical urgency for emphasis strategy. He asked the students to note to him by using utterance as efficient as possible. Then the word "please" was used to soften the utterance.

Further, when the teacher said "You have to listen!" the teacher applied sympathetic advice or warning politeness strategies. It was used to give warning to the students. It was because the students were noisy at that time. Then, when the teacher said "Yes, please", the teacher applied permission that hearer has requested strategy. He allowed the teacher who asked a permission to go to the toilet.

In addition, the utterance indicated the students applied bald on record politeness strategies were when the student said "Stand up! Panganjaliumat" and "Excuse me, sir". Student's first statement was indicated that maximum efficiency politeness strategy was applied. It was applied because the face redress is not required in the conversation because the captain of the class has close relationship with the other students in the class and the entire student agreed that the situation need efficiency utterance to save the time. Then, the second utterance indicated that metaphorical urgency for high valuation of hearer's friendship politeness strategy was applied. The student used this utterance to indicate care feeling to the teacher by using imperative utterance. Then, the utterance has inverted assumption between order and appeal to the relative status between teacher and student. 
The utterances that indicated the teacher considered Payoffs: a prior considerations was when teachers said, "Do you hear it Ari? Ari Kusumahear what I said before"and "Outside? Where?" the first utterance indicated that identity marker politeness strategy especially code switching in-group dialect. The first name "Ari" and become "Ari Kusuma Jaya" was code switching in-group dialect. Then, the second utterance indicated that teacher applied seek agreement politeness strategy. It was used to clarify the information that shared by the student. The teacher repeated the student utterance and gave good feedback that could make the student felt appreciated by the teacher.

In addition, the students' utterances that indicated the politeness by these factors were when the captain of the class said "Let us pray together." The captain said the utterances to make the other students follow the instruction to pray together. Those utterances were similar to include the other student to start the activity together.

The utterances that indicated the influence of circumstances: sociological variables in applying politeness strategy were when the teacher said "Then, please record it, the important one is the voice is your original voice" the utterance was effected by the social variables especially context dependence of absolute ranking. It was because the communication took place in public area. The teacher thought it was important to applied polite language. Even though, he has more authority in that place. He kept to use polite language to give a good model to the students. Then, when the student said "Permit to go out sir" was the respond that was given by the student to teacher question. The student showed her lower status in the utterance by using word "sir" to honor the teacher.

Then, the examples of the utterances that indicated the teacher and the students considered the integration of assessment of payoffs and weighting of risk in the choice of strategies were when teacher said. "Yes, please" was the first example of this factor. It was because the teacher let the students to have the permission. It indirectly fulfill the students desire and to appreciate the students who asked permission by polite expression. Second, the teacher said "Try to listen it again" was influenced by this factor because the teacher did not want to impose the students' negative face. Then, the teacher said "Dipa please assist me, later on I will bring laptop computer to you" was affected by this factor because the teacher fulfill the student's desire first by call his name then asked an assisted by soften his utterance. Those utterances were influenced by the assessment of advantages and the weight of relative power in the communication in the classroom interaction.

\section{Conclusion}

The politeness strategies that were used by the teacher and the students in this study were bald on record, positive politeness, and negative politeness. However, the most politeness strategy that was applied during classroom interaction was negative politeness. Then, it was followed by positive politeness strategy and bald on record. In this study, off record politeness strategy did not applied during the classroom interaction.

The use of bald on record was happened when the teacher gave an order and an advice to the students. Then, the students used it when they asked permission to the teacher. Further, the use of positive politeness was occurred when the teacher and the students clarified the information and indicated someone in the class. Then, the use of negative politeness was occurred when the teacher gave an instruction that consist of a choice in doing it. However, the students used the negative politeness when they showed their respect to the teacher through their utterances.

The factors that was influencing the teacher and the students of X IBB in SMAN 1 Sukasada to choose politeness strategies was payoffs, circumstances and the integration of those both. Payoffs influenced the choice of politeness strategy was occurred when the teacher and the students wanted to keep the relationship and to get good feedback as the advantages. Then, the influence of circumstances was occurred when the teacher gave instruction to the students. Further, the influence of circumstances that affected the students to choose politeness strategy was when they showed their respect to the teacher. It was because the teacher had higher power than they were. Last, the teacher and the students chose politeness strategy that was caused by the integration of the both factors in the previous was because they should use polite language in the formal circumstances and to showing respect to each other.

\section{References}

Agustina, S., \& Cahyono, B. Y. (2016). Politeness and Power Relation in EFL Classroom Interactions: A Study on Indonesian Learners and Lecturers. International Journal of Language and Linguistics, 92-100. 
Bogdan, R., \& Biklen, S. (2007). Qualitative Research for Education: An Introduction to Theory and Methods (5th Edition ed.). United States of America: Pearson Education.

Brown, P., \& Levinson, S. (1987). Politeness: Some universals in language usage. UK: CUP.

Getkham, K. (2014). Politeness Strategies in Thai Graduate Research Paper Discussions: Implications for Second/Foreign Language Academic Writing. English Language Teaching, 159-67.

Kurdghelashvili, T. (2015). Speech Acts and Politeness Strategies in an EFL Classroom in Georgia. International Journal of Cognitive and Language Sciences, 306-309.

Manik, S., \& Hutagaol, J. (2015). An Analysis on Teachers' Politeness Strategy and Student's Compliance in Teaching Learning Process at SD Negeri 024184 Binjai Timur Binjai -North Sumatra-Indonesia. English Language Teaching, 152-170.

Mariani, N. (2016). Developing Students' Intelligent Character through Linguistic Politeness: The Case of English as a Foreign Language for Indonesian Students. English Language Teaching, 101-106.

MTD Training . (2010). Effective Communication Skills . Uineted Kingdom: MTD Training \& Ventus Publishing ApS.

Peng, L., Xie, F., \& Cai, L. (2014). A Case Study of College Teacher's Politeness Strategy in EFL Classroom. Theory and Practice in Language Studies, 110-115.

Puasa, K., Asrifan, A., \& Chen, Y. (2017). Classroom Talk in Bilingual Class Interaction. Research in Pedagogy, 106-121.

Senowarsito. (2013). Politeness Strategies in Teacher-Student Interaction in an EFL Classroom Context. TEFLIN Journal, 82-96.

Sugiyono. (2016). Metode Penelitian Pendidikan: Pendekatan Kuantitatif, Kualitatif, dan R\&D. Bandung: Alafabeta, cv. 